\title{
Use of natural antioxidants in in vitro mammalian embryo production
}

\section{Uso de antioxidantes naturais na produção in vitro de embriões de mamíferos}

\author{
Maria Valéria de Oliveira Santos ${ }^{1}$; Alana Azevedo Borges ${ }^{2}$; Luiza Bento de \\ Queiroz Neta ${ }^{1}$; Luciana Medeiros Bertini ${ }^{3}$; Alexsandra Fernandes Pereira ${ }^{4 *}$
}

\begin{abstract}
In vitro embryo production (IVEP) contributes to the quantitative and qualitative aspects of animal reproduction. Nevertheless, inherent technical factors such as oxidative stress can negatively influence the result and this can impair cell metabolism, thus decreasing the rates of in vitro development, and necessitating the supplementation of culture medium with antioxidants. In this context, compounds of natural origin with this property have been highlighted because of the positive results obtained at different stages of IVEP. Thus, this review aims to present the results obtained by using natural antioxidants to minimize the effects of oxidative stress on gametes and embryos. A variety of natural isolated substances and mixtures (essential oils and extracts) have been studied for supplementation of IVEP media, at stages of in vitro maturation, sperm capacitation, in vitro fertilization, and in vitro development of embryos in different mammalian species. Generally, beneficial effects are observed according to the concentration used, thus demonstrating the potential of several natural antioxidants. Therefore, the main challenges in using these compounds as antioxidants during IVEP include proving their efficiency against free radicals and determining the best concentration at each stage. In addition, understanding the mechanisms of action of such antioxidants is crucial to establishing their use in IVEP biotechnology.
\end{abstract}

Key words: Culture medium. Natural bioactive. Oxidative stress. Reproduction.

\section{Resumo}

A produção in vitro de embriões (PIVE) contribui para os aspectos quantitativos e qualitativos da reprodução animal. Contudo, fatores inerentes da técnica, como o estresse oxidativo, podem influenciar negativamente o resultado e isso pode prejudicar o metabolismo celular, diminuindo assim as taxas de desenvolvimento in vitro, e exigindo a suplementação do meio de cultivo com antioxidantes. Neste contexto, os compostos de origem natural com essa propriedade têm se destacado devido aos resultados positivos obtidos em diferentes estágios da PIVE. Assim, esta revisão pretende apresentar os resultados obtidos usando antioxidantes naturais para minimizar os efeitos do estresse oxidativo em gametas e embriões. Uma variedade de substâncias isoladas e de misturas naturais (óleos essenciais e extratos) tem sido estudada para a suplementação de meios de PIVE, nas etapas de maturação in vitro, capacitação espermática, fecundação in vitro e desenvolvimento in vitro de embriões em diferentes espécies de mamíferos. Geralmente, os efeitos benéficos são observados de acordo com a concentração utilizada,

\footnotetext{
${ }^{1}$ Discentes, Curso de Mestrado, Programa de Pós-Graduação em Ciência Animal, PPGCA, Universidade Federal Rural do SemiÁrido, UFERSA, Mossoró, RN, Brasil. E-mail: valeriasnts07@gmail.com; luizabentoqueiroz@gmail.com

2 Discente, Curso de Doutorado, PPGCA/UFERSA, Mossoró, RN, Brasil. E-mail: alanaazevedob@gmail.com

3 Prof., Instituto Federal do Rio Grande do Norte, IFRN, Apodi, RN, Brasil. E-mail: luciana.bertini@ifrn.edu.br

${ }^{4}$ Prof., UFERSA, Mossoró, RN, Brasil. E-mail: ale_lfcr@yahoo.com.br

* Author for correspondence
} 
demostrando assim o potencial positivo de vários antioxidantes naturais. Portanto, os principais desafios para o uso desses compostos como antioxidantes durante a PIVE incluem provar sua eficiência contra os radicais livres e determinar a melhor concentração em cada etapa. Além disso, a compreensão dos mecanismos de ação de tais antioxidantes é crucial para estabelecer o uso na biotecnologia de PIVE.

Palavras-chave: Bioativo natural. Estresse oxidativo. Meio de cultivo. Reprodução.

\section{Introduction}

In vitro embryo production (IVEP) facilitates production of viable embryos from in vitro procedures that mimic the natural physiological conditions of the female reproductive system. Typically, IVEP can be divided into a few main steps, starting with the recovery of immature cumulus-oocyte complexes, in vitro maturation (IVM), sperm capacitation, in vitro fertilization (IVF), in vitro development (IVD) of possible embryos to the blastocyst stage, and their transfer to synchronized recipients to generate offspring (PARAMIO; IZQUIERDO, 2016). In general, at each stage of IVEP, media with different compositions and supplements are used to stimulate the different reactions required at each developmental phase.

Since the first successful studies performed in small mammals [rabbits (CHANG, 1959), mice (WHITTINGHAM, 1968), and rats (TOYODA; CHANG, 1974)], IVEP has been applied to several species of this class, mainly domestic and production mammals, with different propositions (NAGASHIMA et al., 2015; BULGARELLI et al., 2017). In this sense, over the years, IVEP has promoted numerous benefits to the productive, scientific, and technological sectors (PEREIRA et al., 2012a). Thus, we can cite genetic improvement (NIVET et al., 2012), optimization of the multiplication of animals of commercial interest, increase in offspring/female/year, use of prepubertal (MORIN-DORÉ et al., 2017), pregnant, and lactating females (TAKUMA et al., 2010), use of animals with infertility problems of noncongenital origin, obtaining knowledge about reproductive (SOUZA-FABJAN et al., 2013) and embryonic physiology (CARROCERA et al., 2016), and support in conservation (AVELAR et al., 2012; ARAV, 2014), cloning (PEREIRA et al., 2014), and transgenesis (PEREIRA et al., 2013; CAMPELO et al., 2016) techniques.

Despite many applications, IVEP still presents some limitations with respect to in vitro culture media, which exert a great influence on system maintenance and the result, i.e., the number of viable embryos (PARAMIO; IZQUIERDO, 2016). These media must provide all the nutrients and factors necessary for the development of gametes and embryos, as well as maintain the balance of molecules that can harm the system (CROCOMO et al., 2012; SANTOS et al., 2017). In this regard, one of the main factors that can influence the success of IVEP is oxidative stress caused by the accumulation of reactive oxygen species (ROS) that impair the integrity of cells and their macromolecules thus interfering with in vitro development (ROCHAFRIGONI et al., 2015).

To avoid or minimize oxidative stress, antioxidants have been used as supplements in IVEP media, including enzymes, amino acids, vitamins, and compounds of natural origin such as polyphenols, carotenoids, extracts, and essential oils having this property (TAKAHASHI, 2012). These antioxidants are easily found in nature and have been studied in vitro mainly because of their efficiency against ROS. In addition, during IVEP these natural compounds showed promising results in protecting gametes and embryos from oxidative stress and improving development (MALEKI et al., 2014). Thus, this review aimed to discuss the results obtained with the application of natural antioxidant compounds to minimize the effects of oxidative stress on IVEP in domestic mammals. 


\section{Oxidative stress}

Some factors inherent to IVEP such as oxygen tension, interference of light and heat, presence of sperm, constituents of the medium, and absence of maternal antioxidant protection, are directly related to oxidative stress (CROCOMO et al., 2012). This stress results from an imbalance between ROS and antioxidant substances, with a predominance of the former (ROCHA-FRIGONI et al., 2015).

ROS are represented by a variety of molecules and free radicals produced from oxygen metabolism in biological systems. During cellular respiration, the oxygen molecule $\left(\mathrm{O}_{2}\right)$ must receive four electrons to be completely reduced to two $\mathrm{H}_{2} \mathrm{O}$ molecules. Nevertheless, if $\mathrm{O}_{2}$ is partially reduced by the receipt of only one electron, the product of this reduction will be the superoxide radical $\left(\mathrm{O}_{2}{ }^{-}\right)$ (CROCOMO et al., 2012; TAKAHASHI, 2012). From this radical, other biochemical reactions can lead to the formation of hydrogen peroxide $\left(\mathrm{H}_{2} \mathrm{O}_{2}\right)$ and the hydroxyl radical $(\cdot \mathrm{OH})$ (TAKAHASHI, 2012). All these oxygen-derived metabolites exhibit high instability and reactivity due to at least one unpaired electron in their outer orbit (ROCHAFRIGONI et al., 2015).

In an equilibrium situation, ROS have beneficial effects acting as signaling molecules in physiological processes such as tissue regeneration, hormonal signaling, intracellular redox regulation, and embryogenesis (ZHONG; ZHOU, 2013). However, under conditions of imbalance, ROS can oxidize any cellular molecule such as lipids, carbohydrates, amino acids, and nucleic acids, thus modifying their functions and compromising cell survival (AGARWAL; SALEH, 2002). Therefore, oxidative stress can cause negative effects on viability, gene expression, protein synthesis, development, and molecular signaling of gametes and embryos, aspects that are determinant for the success of IVEP (ZULLO et al., 2016a).

Normally, living organisms possess a wide variety of antioxidants, especially of enzymatic and food origin, that eliminate or suppress ROS formation and activity (BANSAL et al., 2011). Nevertheless, under in vitro stress conditions, endogenous antioxidants may not be sufficient to neutralize the excess free radicals. Therefore, during IVEP, is often necessary to supplement the culture medium with exogenous antioxidants that allow adequate maintenance of cellular activity (LYKKESFELDT; SVENDSEN, 2007).

\section{Use of antioxidants in IVEP media}

Antioxidants are molecules capable of donating electrons to oxidants, which eventually lose their reactivity and become harmless to cellular macromolecules (LYKKESFELDT; SVENDSEN, 2007). These compounds can be classified as enzymatic (i.e., catalase, glutathione peroxidase, and superoxide dismutase) and non-enzymatic (i.e., glutathione, cysteamine and resveratrol). Moreover, antioxidants may be naturally produced inside cells as a defense mechanism or be of exogenous origin from supplementation (BANSAL et al., 2011).

Previous studies have demonstrated that balanced presence of antioxidants and ROS in IVEP media can be beneficial for embryonic development (ALI et al., 2003; ZULLO et al., 2016a). Currently, the most used antioxidant in IVEP protocols is cysteamine, whose efficiency is mainly related to the stage of IVM. This molecule has been shown to act by stimulating embryonic development and the synthesis of glutathione (GSH), a compound naturally present in both gametes with an important role in protecting against the effects of ROS (GOTTARDI et al., 2012). Cysteine and glutathione have also been used in IVEP protocols with good results (ALI et al., 2003; SUN et al., 2015). Recently, the quercetin $(2 \mu \mathrm{M})$, resveratrol $(2 \mu \mathrm{M})$, vitamin $\mathrm{C}$ $(50 \mu \mathrm{g} / \mathrm{mL})$, carnitine $(0.5 \mathrm{mg} / \mathrm{mL})$, and cysteamine $(100 \mu \mathrm{M})$ were evaluated to identify the most efficient antioxidant against the harmful effects of ROS during IVM of bovine oocytes (SOVERNIGO et al., 2017). In this study, the maturation rate with 
antioxidants was similar to that of the control; the blastocyst rate of all antioxidants was superior to the control; however, in the ROS and GSH evaluation, only some groups showed positive results compared to the control, and therefore, it was not possible to determine the most efficient antioxidant. Finally, in IVF, hypotaurine is widely used for its action mimicking the physiological antioxidant conditions of seminal plasma (AGARWAL; SALEH, 2002).

Despite previously observed results, much research has been conducted to establish the use of more efficient antioxidants for all stages of IVEP (GOTTARDI et al., 2012; MALEKI et al., 2016). In this context, the use of natural in vitro antioxidants in culture media has received special attention, mainly due to their efficiency and low cost (WANG et al., 2013; SALZANO etal., 2014). These bioactives have been studied in the IVEP of several species (Table 1); however, positive results are only achieved with the use of appropriate concentrations. Therefore, the main challenge in the cellular antioxidant field is to establish optimal concentrations to minimize oxidative effects without impairing development. This occurs because very low concentrations of all types of antioxidants used in IVEP, natural or not, may have in significant effects whereas high concentrations may have negative effects (ALI et al., 2003; MALEKI et al., 2014; ZULLO et al., 2016a).

\section{Methods for evaluation of antioxidants in IVEP}

In general, to determinate antioxidant efficiency in gametes and embryos, specific and non-specific methods are available. As non-specific methods, morphological and developmental parameters can be evaluated. During IVEP, the maturation rate, sperm parameters, and rates of embryonic development, i.e., the number of embryos that reach the stages of cleavage, blastocyst, and hatched blastocyst, is often calculated (MALEKI et al., 2014). These numbers indicate the efficiency of culture media and the quality of oocytes, spermatozoa, and embryos (SALZANO et al., 2014).

The total number of blastocyst cells is also used as an important parameter in the evaluation of embryonic quality, since it directly influences fetal development (SALZANO et al., 2014). Additionally, this method allows differential counting of the internal cell mass and trophectoderm cells, which must be in an appropriate proportion of $20-40 \%$ (KOO et al., 2002). For this, fluorescent labels such as propidium iodide and Hoechst are usually used (SALZANO et al., 2014). Evaluation of embryonic cryotolerance has also been used as a parameter since competent embryos are more tolerant to cryopreservation procedures (CARROCERA et al., 2016). Thus, the parameters analyzed after thawing include survival and hatching rates after $24 \mathrm{~h}$ and $48 \mathrm{~h}$ of in vitro culture, respectively (AMBROGI et al., 2017).

For more specific methods, quantification of apoptotic cells using the terminal deoxynucleotidyl transferase dUTP Nick end labeling assay (TUNEL assay) is used widely because ROS can cause DNA damage (NGUYEN et al., 2017). Another employed technique is the analysis of gene expression, especially of enzymes involved in the cellular antioxidant system such as catalase, superoxide dismutase, and glutathione peroxidase, and genes related to apoptotic pathways (ESHTIYAGHI et al., 2016; MESALAM et al., 2017). 
Table 1. Natural antioxidants used in different steps of IVEP in mammals.

\begin{tabular}{|c|c|c|c|c|c|}
\hline Natural antioxidants & IVEP step & Species & $\begin{array}{l}\text { Best } \\
\text { concentration }\end{array}$ & BL (\%) & Authors \\
\hline \multicolumn{6}{|c|}{ Isolated substances/compounds } \\
\hline \multirow{2}{*}{ Anthocyanin } & IVD & Bovine & $0.1 \mu \mathrm{g} / \mathrm{mL}$ & 28.7 & Sakatani et al. (2007) \\
\hline & IVM/IVD & Swine & $0.1 \mu \mathrm{g} / \mathrm{mL}$ & 51.0 & You et al. (2010) \\
\hline Crocetin & IVD & Bovine & $1.0 \mu \mathrm{M}$ & 46.1 & Zullo et al. (2016b) \\
\hline \multirow[b]{2}{*}{ Crocin } & IVM & Murine & $10.0 \mu \mathrm{g} / \mathrm{mL}$ & 43.0 & Maleki et al. $(2014,2016)$ \\
\hline & $\begin{array}{l}\text { Capacitation } \\
\text { IVF }\end{array}$ & Bovine & $1.0 \mathrm{mM}$ & 54.2 & Sapanidou et al. (2015) \\
\hline \multirow{2}{*}{ Green tea polyphenols } & IVM & \multirow{2}{*}{ Bovine } & $15.0 \mu \mathrm{M}$ & 38.1 & Wang et al. (2007) \\
\hline & IVD & & $15.0 \mu \mathrm{M}$ & $\mathrm{N}$ & Wang et al. (2013) \\
\hline \multirow{2}{*}{ L-ergothioneine } & IVM & Sheep & $10.0 \mathrm{mM}$ & $\mathrm{N}$ & Öztürkler et al. (2010) \\
\hline & IVD & Bovine & $0.1 \mathrm{mM}$ & 41,5 & Zullo et al. (2016a) \\
\hline \multirow{3}{*}{ Quercetin } & \multirow{2}{*}{ IVM } & Bovine & $2.0 \mu \mathrm{M}$ & 59.5 & Guemra et al. (2013) \\
\hline & & Swine & $1.0 \mu \mathrm{g} / \mathrm{mL}$ & 15.8 & Kang et al. (2013) \\
\hline & Capacitation & Human & $30.0 \mu \mathrm{M}$ & $\mathrm{N}$ & Moretti et al. (2012) \\
\hline \multirow{6}{*}{ Resveratrol } & IVM & \multirow{2}{*}{ Bovine } & $1 \mu \mathrm{M}$ & 30.0 & Wang et al. (2014) \\
\hline & IVD & & $0.5 \mu \mathrm{M}$ & 59.2 & Salzano et al. (2014) \\
\hline & IVM & Swine & $2 \mu \mathrm{M}$ & 62.1 & Kwak et al. (2012) \\
\hline & \multirow{3}{*}{ Capacitation } & Bovine & $5-50 \mu \mathrm{M}$ & $\mathrm{N}$ & Tvrdá et al. (2015) \\
\hline & & Murine & $15 \mu \mathrm{g} / \mathrm{mL}$ & $\mathrm{N}$ & Mojica-Villegas et al. (2014) \\
\hline & & Human & $0.1 \mathrm{mM}$ & $\mathrm{N}$ & Garcez et al. (2010) \\
\hline Rutin & \multirow{3}{*}{ Capacitation } & \multirow{3}{*}{ Human } & $30.0 \mu \mathrm{M}$ & $\mathrm{N}$ & \\
\hline Naringenin & & & $\mathrm{X}$ & $\mathrm{N}$ & Moretti et al. (2012) \\
\hline Epicatechin & & & $\mathrm{X}$ & $\mathrm{N}$ & \\
\hline \multirow{2}{*}{ Verbascoside } & \multirow{2}{*}{ IVM } & \multirow{2}{*}{ Sheep } & $1.03 \mu \mathrm{M}^{*}$ & 31.2 & Dell'aquila et al. (2014) \\
\hline & & & $1 \mathrm{nM}$ & 37.8 & Martino et al. (2016) \\
\hline 2-Methoxystypandrone & IVM & Bovine & $1 \mu \mathrm{M}$ & 45.3 & Mesalam et al. (2017) \\
\hline \multicolumn{6}{|c|}{ Essential oils and extracts } \\
\hline \multirow{2}{*}{$\begin{array}{l}\text { Aqueous extract of } \\
\text { Crocus sativus L. }\end{array}$} & \multirow{2}{*}{ IVM } & \multirow{2}{*}{ Murine } & $5.0 \mu \mathrm{g} / \mathrm{mL}$ & 29.8 & Tavana et al. (2012) \\
\hline & & & $40.0 \mathrm{mg} / \mathrm{mL}$ & 38.0 & Maleki et al. (2014) \\
\hline \multirow{2}{*}{$\begin{array}{l}\text { Ethanolic extract of } \\
\text { Papaver rhoeas L. }\end{array}$} & \multirow{2}{*}{ IVM } & Murine & $100 \mu \mathrm{g} / \mathrm{mL}$ & 34.8 & Golkar-Narenji et al. (2010) \\
\hline & & Sheep & $50 \mu \mathrm{g} / \mathrm{mL}$ & $\mathrm{N}$ & Rajabi-Toustani et al. (2013) \\
\hline $\begin{array}{l}\text { Essential oil of Lippia } \\
\text { origanoides }\end{array}$ & IVM & $\begin{array}{l}\text { Bovine } \\
\text { Buffaloes }\end{array}$ & $\begin{array}{l}2.0,5.0-10.0 \mu \mathrm{g} / \\
\mathrm{mL}^{*}\end{array}$ & $24.0-35.0$ & Sollecito et al. (2016) \\
\hline $\begin{array}{l}\text { Essential oil of Thymus } \\
\text { munbyanus }\end{array}$ & Capacitation & Human & $\mathrm{X}$ & $\mathrm{N}$ & Chikhoune et al. (2015) \\
\hline Royal jelly & IVM & Sheep & $10.0 \mathrm{mg} / \mathrm{mL}$ & 39.6 & Eshtiyaghi et al. (2016) \\
\hline
\end{tabular}

BL: blastocyst rate. N: not evaluated. X: concentrations evaluated have no positive effect for IVEP. ${ }^{*}$ There was no statistical difference compared to the control without antioxidant.

Moreover, quantification of ROS levels using a fluorescentmarker $\left(2^{\prime}, 7^{\prime}\right.$-dichlorodihydrofluorescein diacetate) allows specific evaluation of the antioxidant ability to reduce intracellular ROS (AMBROGI et al., 2017). In addition, it is also possible to check the levels of glutathione, an antioxidant produced by the cell. Some antioxidant compounds also act by stimulating the production of intracellular glutathione to act against ROS and thus reduce oxidative stress (SOVERNIGO et al., 2017). Therefore, this analysis is performed using the fluorescent label 4-chloromethyl-6, 8-difluoro- 
7-hydroxycoumarin (KWAK et al., 2012). Another in use is the measurement of mitochondrial membrane potential in gametes and embryos, as increased activity of this organelle can increase the ROS production (MOJICA-VILLEGAS et al., 2014; AMBROGI et al., 2017).

Therefore, non-specific parameters are very important to predict the efficiency of the culture system as well as the quality and competence of the gametes and embryos used for the experiments. However, these parameters are used in association with specific methods to obtain more consistent and accurate data, which allow a more direct evaluation of antioxidant activity and contribute to understanding the possible mechanisms of action of the tested compounds.

\section{Natural antioxidants}

There are several methods for obtaining essential oils, extracts, and isolation of specific bioactives. The most traditional and commonly used methods for obtaining essential oils are hydrodistillation, steam distillation, solvent extraction, enfleurage, cohobation, and maceration (HESHAM et al., 2016). For extracts, the most common techniques are maceration, decoction, infusion, and percolation, with variations in the solvents used (AZWANIDA, 2015). One limitation for the use of such compounds is their chemical composition which may vary according to the extraction method and solvent, as well as the place of origin of the plant, the time of the year, and time of the day. This fact may hinder the reproducibility of results. In contrast, isolated substances allow greater control over the bioactive that will be tested. For this, chromatographic techniques, especially high performance liquid chromatography, and immunoassays have been used (SASIDHARAN et al., 2011).

\section{Isolated substances/compounds}

Among isolated compounds with their antioxidant action evaluated in IVEP, resveratrol is certainly one of the most studied (SALZANO et al., 2014). This polyphenol (non-flavonoid) is naturally present in several plant species with a protective function and when isolated, shows several therapeutic properties, such as anticancer (JANG et al., 1997), anti-diabetic (PALSAMY; SUBRAMANIAN, 2008), and cardioprotective properties (SZMITKO; VERMA, 2005) including antioxidant activity (BHAT et al., 2001). Therefore, application of resveratrol in IVEP showed good results in relation to protection against oxidative stress, decreasing ROS levels, and increasing GSH levels (KWAK et al., 2012; WANG et al., 2014). Wang et al. (2014) observed higher maturation rate (93.4\%), increased quality (cells/blastocyst: 118.7) and rates of bovine embryo development (30.0\%) after addition of 1.0 $\mu \mathrm{M}$ of resveratrol during IVM, compared to $0,0.1$, and $10.0 \mu \mathrm{M}$. At the same IVEP step with porcine oocytes, supplementation of the medium with 2.0 $\mu \mathrm{M}$ of resveratrol improved oocyte quality $(88.3 \%)$, monospermal fertilization (54.1\%) and embryo development (62.1\%) (KWAK et al., 2012). In sperm capacitation, resveratrol was beneficial for stimulation of sperm activity, the protection against lipid peroxidation, and the maintenance of fertility [cattle (TVRDÁ et al., 2015), murine (MOJICAVILLEGAS et al., 2014), human (GARCEZ et al., 2010)]. In addition, when used in IVD medium, this antioxidant at a concentration of $0.5 \mu \mathrm{M}$, could improve the cryotolerance of vitrified embryos with an increased rate of hatching (58.9\%) after warming (SALZANO et al., 2014).

Another polyphenol that has been studied in IVEP is quercetin, which can be found at high concentrations in black tea, red wine, fruits, and vegetables (GUEMRA et al., 2013). This flavonoid exerts various pharmacological effects such as anti- 
inflammatory and antioxidant activities (DAVIS et al., 2009). Due to its antioxidant and metal chelating potential, supplementation with quercetin $(2.0 \mu \mathrm{M})$ in IVM of bovine oocytes induced improvement in the blastocyst rate $(59.5 \%)$, which was higher than that obtained with cysteamine $(50.4 \%)$ and in the control without the antioxidant (42.3\%) (GUEMRA et al., 2013). In porcine oocytes during IVM, treatment with $1.0 \mu \mathrm{g} / \mathrm{mL}$ of quercetin reduced the intracellular ROS levels and significantly improved blastocyst development (15.8\%) (KANG et al., 2013). Moretti et al. (2012) evaluated quercetin, rutin, naringenin and epicatechin, all flavonoids found naturally in plants, of which only quercetin $(30.0 \mu \mathrm{M})$ and rutin $(30.0 \mu \mathrm{M})$ conferred protection against lipid peroxidation.

Recently, crocin and crocetin, which are carotenoids responsible for the antitumor and antioxidant activity of saffron extract (Crocus sativus L.), were evaluated in IVEP. Maleki et al. (2014) evaluated high concentrations [0, 50.0, 100.0, $400.0 \mu \mathrm{g} / \mathrm{mL}]$ and Maleki et al. (2016) used low concentrations $[0,5.0,10.0 \mu \mathrm{g} / \mathrm{mL}]$ of crocin in the maturation medium of murine oocytes and obtained better rates of maturation $(75.0 \%)$, cleavage $(47.0 \%)$, blastocysts $(43.0 \%)$, and increased GSH concentration when they used $10.0 \mu \mathrm{g} / \mathrm{mL}$ of this antioxidant. Moreover, when crocin was added to the medium of bovine sperm capacitation, satisfactory results obtained both in sperm quality parameters (motility, intact acrosome, acrosome reaction, and DNA fragmentation) as well as in IVF and IVD using these gametes (SAPANIDOU et al., $2015)$. In this study, the blastocyst rate $(54.2 \%)$ was significantly higher with the addition of $1.0 \mathrm{mM}$ of crocin in sperm capacitation compared to the control without antioxidant (37.5\%) (SAPANIDOU et al., 2015). Crocetin was used in the IVD medium, where a concentration of $1.0 \mu \mathrm{M}$ could significantly improve the blastocyst rate $(46.1 \%)$ and embryo quality by decreasing the percentage of apoptotic cells and increasing cryotolerance (ZULLO et al., 2016b).
L-ergothioneine is a thiol compound synthesized by fungi and bacteria that can be easily found in some types of mushrooms, and has chemical properties and physiological functions suitable for an in vitro cytoprotectant (CHEAH; HALLIWELL, 2012). This compound when isolated shows antioxidant activity, which was evidenced in IVEP studies in sheep, and was used as a supplement in IVM and IVD medium $(10.0 \mathrm{mM})$ resulting in increased maturation (80.4\%), cleavage $(29.9 \%)$, and morula (6.5\%) rates (ÖZTÜRKLER et al., 2010). In addition, in the IVD medium of bovine embryos, L-ergothioneine $(0.1 \mathrm{mM})$ improved the quality and cryotolerance and decreased the apoptosis rate in blastocysts (ZULLO et al., 2016a).

Another interesting compound of sustainable origin studied at IVEP is verbascoside (polyphenol), which is present in olive oil, has anti-inflammatory activity and was obtained from wastewater from the production of this oil. However, despite good results in relation to the reduction of ROS levels in cell culture (CARDINALI et al., 2012), when verbascoside was used in IVM by Dell'aquila et al. (2014), no improvement was observed in any of the development parameters evaluated. In this study, the $1.03 \mu \mathrm{M}$ concentration was similar to the control without antioxidant on the blastocyst rate (31.2 vs. 24\%), but larger amounts (2.06 and 4.11 $\mu \mathrm{M})$ of verbascoside showed a negative effect (11.5 and $11.9 \%$ ). Furthermore, for unknown reasons, a significant increase was observed at the ROS levels (DELL'AQUILA et al., 2014). Nevertheless, Martino et al. (2016) noted that $1 \mathrm{nM}$ of verbascoside had a beneficial effect on embryo development to the blastocyst stage (37.8vs. 27.3\%) and blastocyst quality by acting as an antioxidant molecule, as it reduced oocyte ROS and maintained mitochondrial activity at basal levels.

Recently, 2-methoxystypandrone, a naphthoquinone purified from Polygonum cuspidatum (known as "Huzhang"), which is used in food, cosmetics, and pharmaceuticals, was evaluated for the first time during IVM of bovine 
oocytes at concentrations of $0.1,0.5,1$, and 1.5 $\mu \mathrm{M}$. It was observed that $1.0 \mu \mathrm{M}$ of this substance increases the blastocyst rate and the number of total cells, decreases apoptosis and ROS levels, and influences the expression of genes important for embryonic development (MESALAM et al., 2017).

Another substance called anthocyanin, which also has various biological activities, was extracted from Ipomoea batatas (purple sweet potato) and evaluated $(0.1,1.0,10.0 \mu \mathrm{g} / \mathrm{mL})$ during IVD in cattle (SAKATANI et al., 2007). It was observed that low concentration $(0.1 \mu \mathrm{g} / \mathrm{mL})$ of anthocyanin has a similar effect to control under normal conditions, but under conditions of heat shock, anthocyanin protects embryos by improving development, reducing oxidative stress, and increasing the intracellular GSH levels. You et al. (2010) used anthocyanin at $0.1 \mu \mathrm{g} / \mathrm{mL}$ during IVM and/or IVD for parthenogenetic activation (PA) and cloning by somatic cell nuclear transfer (SCNT) in swine. In this study, oocytes treated with anthocyanin during IVM showed higher rates of blastocyst formation after PA (55.7 vs. 44.9\%) and SCNT (32.2 vs. $16.1 \%$ ) compared to untreated oocytes. Moreover, in PA and SCNT embryos, anthocyanin treatment during IVM or IVD significantly increased the intracellular GSH level resulting in reduced ROS levels (YOU et al., 2010).

Green tea polyphenols have been shown to be useful anti-diabetic, antitumor and antioxidant agents and were also evaluated in IVEP of cattle as natural antioxidants. Initially, Wang et al. (2007) evaluated these compounds during IVM and obtained better rates of maturation $(86.1 \%)$, fertilization $(79.9 \%)$, and embryonic development (38.1\%) at a concentration of $15.0 \mu \mathrm{M}$, correlating this effect with the higher level of intracellular GSH in treated oocytes. Afterwards, Wang et al. (2013) also evaluated the molecular parameters of bovine embryos and transfer to synchronized recipients after IVM and IVD with green tea polyphenols. In this study, the expression of antioxidant enzyme genes (superoxide dismutase, catalase, and glutathione peroxidase) was increased and the apoptosis rate was decreased; the pregnancy rate after 30 and 60 days was also higher with the addition of $15.0 \mu \mathrm{M}$ of the antioxidant in relation to the control without antioxidant.

Considering these results, these substances show remarkable potential for use with gametes and embryos at all steps of IVEP. Since there is a growing interest in increasing the rates of embryonic development for all species, it is important to know that there are natural compounds that can contribute to these improvements with high efficiency. Many of these antioxidant substances have been discovered through studies of mixtures such as extracts and essential oils from plants in cell culture and pharmacological studies (CARDINALI et al., 2012; MALEKI et al., 2014). Thus, the effect of these mixtures has also been studied in IVEP biotechnology.

\section{Essential oils and extracts}

In general, extracts and essential oils are rich in phenolic compounds, carotenoids, terpenes, and other organic substances that have varied therapeutic properties (PEREIRA et al., 2012b) such as antioxidant activity (ESHTIYAGHI et al., 2016). Some of these compounds have also been studied in IVEP as antioxidants though they were not purified and of variable composition. The aqueous extract of Crocus sativus L. or saffron was evaluated during the IVM of murine oocytes and presented a beneficial effect increasing the rates of oocyte and embryo development (TAVANA et al., 2012; MALEKI et al., 2014). In studies evaluating this extract, concentrations ranging from 5-40 $\mu \mathrm{g} /$ $\mathrm{mL}$ were tested; Tavana et al. (2012) obtained better blastocyst rate $(29.8 \%)$ with a concentration of 5.0 $\mu \mathrm{g} / \mathrm{mL}$ whereas Maleki et al. (2014) obtained better rates of maturation $(76.0 \%)$, cleavage $(78.0 \%)$, and blastocyst (38.0\%) with $40.0 \mu \mathrm{g} / \mathrm{mL}$ of the extract.

The ethanolic extract of Papaver rhoeas L. was evaluated during the IVM of murine oocytes at low 
concentrations $(0.0,10.0,15.0,20.0$, and $25.0 \mu \mathrm{g} /$ $\mathrm{mL})$ and high concentrations $(0.0,50.0,100.0$, and $200 \mu \mathrm{g} / \mathrm{mL}$ ). Among the concentrations used, 100.0 $\mu \mathrm{g} / \mathrm{mL}$ promoted an increase in the maturation rate (70.7 vs. 56.3\%) and developmental competence of embryos (34.8 vs. 18.8\%) compared to those in control group. In addition, the $P$. rhoeas extract at concentration of $50.0 \mu \mathrm{g} / \mathrm{mL}$ also showed a positive effect on the maturation rate of sheep oocytes compared to the control group (70.1 vs. 54.7\%) (RAJABI-TOUSTANI et al., 2013).

Recently, the essential oil of Lippia origanoides (wild oregano), which is rich in carvacrol and thymol, was evaluated in the IVM medium of bovine and buffalo oocytes. However, at the concentrations tested $(2.5,5.0$, and $10.0 \mu \mathrm{g} / \mathrm{mL})$, no differences were observed in the rates of embryonic development (26-35\%) (SOLLECITO et al., 2016). In addition, there was no difference in the $\mathrm{H}_{2} \mathrm{O}_{2}$ concentrations in the media of the evaluated treatments. The essential oil of Thymus munbyanus (thyme) was evaluated in the capacitation of human sperm but no improvement in viability and motility was observed (CHIKHOUNE et al., 2015).

Finally, royal jelly, a highly nutritious blend with antioxidant properties, was also evaluated (2.5, 5.0, and $10.0 \mathrm{mg} / \mathrm{mL}$ ) during the IVM of ovine oocytes. In this study, $10.0 \mathrm{mg} / \mathrm{mL}$ of royal jelly showed better rates of development of oocytes $(85.6 \%)$ and embryos (39.6\%), increased expression of antioxidant enzyme genes (superoxide dismutase, catalase and glutathione peroxidase) in cumulus cells and increased intracellular GSH levels (ESHTIYAGHI et al., 2016).

\section{Conclusion}

Considering the need for antioxidant compounds to reduce oxidative stress during IVEP, studies aiming to establish this type of supplement are essential, since each step presents different requirements. In this context, natural antioxidants are a viable low cost alternative with very promising results. These compounds have been used in isolated form and as mixtures with results highly dependent on the concentrations used in the medium. Thus, the main challenges for the use of natural compounds as antioxidants during IVEP are to prove their efficiency against ROS and to determine the best concentration at each step. In addition, in relation to essential oils and extracts, reproducibility of the results may be difficult due to variation in composition according to the season and origin of the plant. Therefore, it is expected that these and other natural antioxidants will be studied during IVEP and their mechanisms of action will be deciphered, thus contributing to greater success of this technique. Finally, such studies may also contribute to research with in vitro cell cultures under oxidative stress and to studies in the field of pharmacology.

\section{References}

AGARWAL, A.; SALEH, R. A. Role of oxidants in male infertility: rationale, significance, and treatment. Urologic Clinics of North America, Philadelphia, v. 29, n. 4 , p. 817-827, 2002.

ALI, A. A.; BILODEAU, J. F.; SIRARD, M. A. Antioxidant requirements for bovine oocytes varies during in vitro maturation, fertilization and development. Theriogenology, New York, v. 59, n. 3, p. 939-949, 2003.

AMBROGI, M.; DALL'ACQUA, P. C.; ROCHAFRIGONI, N.; LEÃO, B.; MINGOTI, G. Z. Transporting bovine oocytes in a medium supplemented with different macromolecules and antioxidants: effects on nuclear and cytoplasmic maturation and embryonic development in vitro. Reproduction in Domestic Animal, Linköping, v. 52, n. 3, p. 409-421, 2017.

ARAV, A. Cryopreservation of oocytes and embryos. Theriogenology, New York, v. 81, n. 1, p. 96-102, 2014.

AVELAR, S. R. G.; MOURA, R. R.; SOUSA, F. C.; PEREIRA, A. F.; ALMEIDA, K. C.; MELO, C. H. S.; TEIXEIRA, D. I. A.; FREITAS, V. J. F. Oocyte production and in vitro maturation in Canindé goats following hormonal ovarian stimulation. Animal Reproduction, Belo Horizonte, v. 9, n. 1, p. 27-32, 2012. 
AZWANIDA, N. N. A review on the extraction methods use in medicinal plants, principle, strength and limitation. Medicinal \& Aromatic Plants, Los Angeles. v. 4, n. 196, p. 1-6, 2015.

BANSAL, A. K.; CHEEMA, R. S.; GANDOTRA, V. K. Antioxidant effect of $\mathrm{Mn}^{2+}$ on capacitation and acrosome reaction of fresh and chilled cattle bull semen. Veterinary Science Development, Pavia, v. 1, n. 1, p. 69-71, 2011.

BHAT, K. P. L.; KOSMEDER, J. W.; PEZZUTO, J. M. Biological effects of resveratrol. Antioxidants and Redox Signaling, New York, v. 3, n. 6, p. 1041-1064, 2001.

BULGARELLI, D. L.; VIREQUE, A. A.; PITANGUIMOLINA, C. P.; SILVA-DE-SÁ, M. F.; SÁ ROSA, A. C. J. Reduced competence of immature and mature oocytes vitrified by Cryotop method: assessment by in vitro fertilization and parthenogenetic activation in a bovine model. Zygote, Cambridge, v. 25, n. 2, p. 222-230, 2017.

CAMPELO, I. S.; PEREIRA, A. F.; ALCÂNTARANETO, A. S.; CANEL, N. G.; SOUZA-FABJAN, J. M.; TEIXEIRA, D. I.; CAMARGO, L. S. A.; MELO, L. M.; RÁDIS-BAPTISTA, G.; SALAMONE, D. F.; FREITAS, V. J. F. Effect of crotamine, a cell-penetrating peptide, on blastocyst production and gene expression of in vitro fertilized bovine embryos. Zygote, Cambridge, v. 24, n. 1, p. 48-57, 2016.

CARDINALI, A.; PATI, S.; MINERVINI, F.; D'ANTUONO, I.; LINSALATA, V.; LATTANZIO, V. Verbascoside, isoverbascoside, and their derivatives recovered from olive mill wastewater as possible food antioxidants. Journal of Agricultural and Food Chemistry, Washington, v. 60, n. 7, p. 1822-1829, 2012.

CARROCERA, S.; CAAMAÑO, J. N.; TRIGAL, B.; MARTÍN, D.; DÍEZ, C. Developmental kinetics of in vitro-produced bovine embryos: an aid for making decisions. Theriogenology, New York, v. 85, n. 5, p. 822$827,2016$.

CHANG, M. C. Fertilization of rabbit ova in vitro. Nature, London, v. 184, n. 4684, p. 466-467, 1959.

CHEAH, I. K.; HALLIWELL, B. Ergothioneine; antioxidant potential, physiological function and role in disease. Biochimica et Biophysica Acta (BBA)-Molecular Basis of Disease, Amsterdam, v. 1822, n. 5, p. 784-793, 2012.

CHIKHOUNE, A.; STOUVENEL, L.; IGUER-OUADA, M.; HAZZIT, M.; SCHMITT, A.; LORÈS, P.; WOLF, J. P.; AISSAT, K.; AUGER, J.; VAIMAN, D.; TOURÉ, A. In vitro effects of Thymus munbyanus essential oil and thymol on human sperm motility and function. Reproductive Biomedicine Online, Cambridge, v. 31, n. 3, p. 411-420, 2015.
CROCOMO, L. F.; MARQUES FILHO, W. C.; LANDIMALVARENGA, F. D. C.; BICUDO, S. D. In vitro embryo production: oxidative stress and antioxidants. Veterinária e Zootecnia, Botucatu, v. 19, n. 4, p. 470-479, 2012.

DAVIS, J. M.; MURPHY, E. A.; CARMICHAEL, M. D.; DAVIS, B. Quercetin increases brain and muscle mitochondrial biogenesis and exercise tolerance. American Journal of Physiology Regulatory, Integrative and Comparative Physiology, New York, v. 296, n. 1, p. 1071-1077, 2009.

DELL'AQUILA, M. E.; BOGLIOLO, L.; RUSSO, R.; MARTINO, N. A.; FILIOLI URANIO, M.; ARIU, F.; AMATI, F.; SARDANELLI, A. M.; LINSALATA, V.; FERRUZZI, M. G.; CARDINALI, A.; MINERVINI, F. Prooxidant effects of verbascoside, a bioactive compound from olive oil mill wastewater, on in vitro developmental potential of ovine prepubertal oocytes and bioenergetic/ oxidative stress parameters of fresh and vitrified oocytes. BioMed Research International, New York, v. 2014, n. 2014, p. 1-14, 2014.

ESHTIYAGHI, M.; DELDAR, H.; PIRSARAEI, Z. A.; SHOHREH, B. Royal jelly may improve the metabolism of glucose and redox state of ovine oocytes matured in vitro and embryonic development following in vitro fertilization. Theriogenology, New York, v. 86, n. 9, p. 2210-2221, 2016.

GARCEZ, M. E.; BRANCO, C. S.; LARA, L. V.; PASQUALOTTO, F. F.; SALVADOR, M. Effects of resveratrol supplementation on cryopreservation medium of human semen. Fertility and Sterility, New York, v. 94, n. 6, p. 2118-2121, 2010.

GOLKAR-NARENJI, A.; EIMANI, H.; SAMADI, F.; HASANI, S.; SHAHVERDI, A. H.; EFTEKHARIYAZDI, P.; KAMALINEJAD, M. Effect of Papaver rhoeas extract on in vitro maturation and developmental competence of immature mouse oocytes. Reproductive Medicine and Biology, Tokyo, v. 9, n. 4, p. 211-215, 2010.

GOTTARDI, F. P.; BARRETTO, L. S. S.; GONÇALVES, F. S.; PERRI, S. H. V.; MINGOTI, G. Z. Effects of cumulus cells and cysteamine during bovine oocyte in vitro maturation on meiosis progression and acquisition of developmental competence. Arquivo Brasileiro de Medicina Veterinária e Zootecnia, Belo Horizonte, v. 64, n. 2, p. 245-252, 2012.

GUEMRA, S.; MONZANI, P. S.; SANTOS, E. S.; ZANIN, R.; OHASHI, O. M.; MIRANDA, M. S.; ADONA, P. R. In vitro maturation of bovine oocytes in medium supplemented with quercetin, and its effect on embryonic development. Arquivo Brasileiro de Medicina Veterinária e Zootecnia, Belo Horizonte, v. 65, n. 6, p. 1616-1624, 2013. 
HESHAM, H. A. R.; ABDURAHMAN, H. N.; ROSLI, M. Y. Techniques for extraction of essential oils from plants: a review. Australian Journal of Basic and Applied Sciences, Faisalabad, v. 10, n. 16, p. 117-127, 2016.

KANG, J. T.; KWON, D. K.; PARK, S. J.; KIM, S. J.; MOON, J. H.; KOO, O. J.; GOO, J.; LEE, B. C. Quercetin improves the in vitro development of porcine oocytes by decreasing reactive oxygen species levels. Journal of Veterinary Science, New York, v. 14, n. 1, p. 15-20, 2013.

KOO, D. B.; KANG, Y. K.; CHOI, Y. H.; PARK, J. S.; KIM, H. N.; OH, K. B.; HAN, Y. M. Aberrant allocations of inner cell mass and trophectoderm cells in bovine nuclear transfer blastocysts. Biology of Reproduction, New York, v. 67, n. 2, p. 487-492, 2002.

KWAK, S. S.; CHEONG, S. A.; JEON, Y.; LEE, E.; CHOI, K. C.; JEUNG, E. B.; HYUN, S. H. The effects of resveratrol on porcine oocyte in vitro maturation and subsequent embryonic development after parthenogenetic activation and in vitro fertilization. Theriogenology, New York, v. 78, n. 1, p. 86-101, 2012.

JANG, M.; CAI, L.; UDEANI, G. O.; SLOWING, K. V.; THOMAS, C. F.; BEECHER, C. W.; FONG, H. H.; FARNSWORTH, N. R.; KINGHORN, A. D.; MEHTA, R. G.; MOON, R. C.; PEZZUTO, J. M. Cancer chemopreventive activity of resveratrol, a natural product derived from grapes. Science, New York, v. 275, n. 1, p. 218-220, 1997.

LYKKESFELDT, J.; SVENDSEN, O. Oxidants and antioxidants in disease: oxidative stress in farm animals. The Veterinary Journal, London, v. 173, n. 3, p. 502-511, 2007.

MALEKI, E. M.; EIMANI, H.; BIGDELI, M. R.; EBRAHIMI, B.; SHAHVERDI, A. H.; NARENJI, A. G.; ABEDI, R. A comparative study of saffron aqueous extract and its active ingredient, crocin on the in vitro maturation, in vitro fertilization, and in vitro culture of mouse oocytes. Taiwanese Journal of Obstetrics and Gynecology, Hong Kong, v. 53, n. 1, p. 21-25, 2014.

MALEKI, E. M.; EIMANI, H.; BIGDELI, M. R.; NARENJI, A. G.; ABEDI, R. Effects of crocin supplementation during in vitro maturation of mouse oocytes on glutathione synthesis and cytoplasmic maturation. International Journal of Fertility \& Sterility, Tehran, v. 10, n. 1, p. 53-61, 2016.

MARTINO, N. A.; ARIU, F.; BEBBERE, D.; URANIO, M. F.; CHIRICO, A.; MARZANO, G.; SARDANELLI, A. M.; CARDINALI, A.; MINERVINI, F.; BOGLIOLO, L.; DELL'AQUILA, M. E. Supplementation with nanomolar concentrations of verbascoside during in vitro maturation improves embryo development by protecting the oocyte against oxidative stress: a large animal model study. Reproductive Toxicology, New York, v. 65, n. 1, p. 204-211, 2016.

MESALAM, A.; KHAN, I.; LEE, K. L.; SONG, S. H.; CHOWDHURY, M. M. R.; UDDIN, Z.; KONG, I. K. 2-Methoxystypandrone improves in vitro-produced bovine embryo quality through inhibition of IKBKB. Theriogenology, New York, v. 99, n. 1, p. 10-20, 2017.

MOJICA-VILLEGAS, M. A.; IZQUIERDO-VEGA, J. A.; CHAMORRO-CEVALLOS, G.; SÁNCHEZGUTIÉRREZ, M. Protective effect of resveratrol on biomarkers of oxidative stress induced by iron/ascorbate in mouse spermatozoa. Nutrients, Basel, v. 6, n. 2, p. 489503, 2014.

MORETTI, E.; MAZZI, L.; TERZUOLI, G.; BONECHI, C.; IACOPONI, F.; MARTINI, S.; ROSSI, C.; COLLODEL, G. Effect of quercetin, rutin, naringenin and epicatechin on lipid peroxidation induced in human sperm. Reproductive Toxicology, Louisville, v. 34, n. 4, p. 651-657, 2012.

MORIN-DORÉ, L.; BLONDIN, P.; VIGNEAULT, C.; GRAND, F. X.; LABRECQUE, R.; SIRARD, M. A. Transcriptomic evaluation of bovine blastocysts obtained from peri-pubertal oocyte donors. Theriogenology, New York, v. 93, n. 3, p. 111-123, 2017.

NAGASHIMA, J. B.; SYLVESTER, S. R.; NELSON, J. L.; CHEONG, S. H.; MUKAI, C.; LAMBO, C.; FLANDERS, J. A.; MEYERS-WALLEN, V. N.; SONGSASEN, N.; TRAVIS, A. J. Live births from domestic dog (Canis familiaris) embryos produced by in vitro fertilization. Plos One, Nevada, v. 10, n. 12, p. 1-13, 2015.

NIVET, A. L.; BUNEL, A.; LABRECQUE, R.; BELANGER, J.; VIGNEAULT, C.; BLONDIN, P.; SIRARD, M. A. FSH withdrawal improves developmental competence of oocytes in the bovine model. Reproduction, Teddington, v. 143, n. 2, p. 165171, 2012.

NGUYEN, T. V.; TANIHARA, F.; DO, L.; SATO, Y.; TANIGUCHI, M.; TAKAGI, M.; VAN NGUYEN, T.; OTOI, T. Chlorogenic acid supplementation during in vitro maturation improves maturation, fertilization and developmental competence of porcine oocytes. Reproduction in Domestic Animals, Linköping, doi: 10.1111/rda.13005, 2017, 1-7.

ÖZTÜRKLER, Y.; YILDIZ, S.; GÜNGÖR, Ö.; PANCARCI, S. M.; KACAR, C.; ARI, U. C. The effects of L-ergothioneine and L-ascorbic acid on the in vitro maturation (IVM) and embryonic development (IVC) of sheep oocytes. Kafkas Üniversitesi Veteriner Fakültesi Adina Sahibi, Dhekan, v. 16, n. 5, p. 5-14, 2010. 
PALSAMY, P.; SUBRAMANIAN, S. Resveratrol, a natural phytoalexin, normalizes hyperglycemia in streptozotocin-nicotinamide induced experimental diabetic rats. Biomedicine \& Pharmacotherapy, New York, v. 62, n. 1, p. 598-605, 2008.

PARAMIO, M. T.; IZQUIERDO, D. Recent advances in in vitro embryo production in small ruminants. Theriogenology, New York, v. 86, n. 1, p. 152-159, 2016.

PEREIRA, A. F.; ALCÂNTARA NETO, A. S.; ALBUQUERQUE, E. S.; LUCIANO, M. C. S.; TEIXEIRA, D. I. A.; FREITAS, V. J. F.; MELO, L. M. Goat oocyte production by standard or one-shot FSH treatments and quantitative analysis of transcripts for EGF ligands and its receptor after in vitro maturation. Reproduction in Domestic Animals, Linköping, v. 47, n. 2, p. 244-251, 2012a.

PEREIRA, A. F.; FELTRIN, C.; ALMEIDA, K. C.; CARNEIRO, I. S.; AVELAR, S. R. G.; ALCÂNTARA NETO, A.; SOUSA, F. C.; MELOA, C. H. S.; MOURA, R. R.; TEIXEIRA, D. I. A.; BERTOLINI, L. R.; FREITAS, V. J. F.; BERTOLINI, M. Analysis of factors contributing to the efficiency of the in vitro production of transgenic goat embryos (Capra hircus) by handmade cloning (HMC). Small Ruminant Research, Amsterdam, v. 109, n. 2, p. 163-172, 2013.

PEREIRA, A. F.; MELO, L. M.; FREITAS, V. J. F.; SALAMONE, D. F. Phosphorylated H2AX in parthenogenetically activated, in vitro fertilized and cloned bovine embryos. Zygote, Cambridge, v. 23, n. 4, p. 485-493, 2014.

PEREIRA, A. F.; MELO, L. M.; MORAIS, S. M.; LEALCARDOSO, J. H.; FREITAS, V. J. F. Relaxant effect of the essential oil of Croton nepetifolius on ovine cervix. Revista Brasileira de Farmacognosia, Curitiba, v. 22, n. 3, p. 522-527, 2012 b.

RAJABI-TOUSTANI, R.; MOTAMEDI-MOJDEHI, R.; MEHR, M. R. A.; MOTAMEDI-MOJDEHI, R. Effect of Papaver rhoeas $\mathrm{L}$. extract on in vitro maturation of sheep oocytes. Small Ruminant Research, New York, v. 114, n. 1, p. 146-151, 2013.

ROCHA-FRIGONI, N. A. S.; SILVA LEÃO, B. C.; NOGUEIRA, É.; ACCORSI, M. F.; MINGOTI, G. Z. Effects of gaseous atmosphere and antioxidants on the development and cryotolerance of bovine embryos at different periods of in vitro culture. Zygote, Cambridge, v. 23 , n. 2 , p. $159-168,2015$

SAKATANI, M.; SUDA, I.; OKI, T.; KOBAYASHI, S. I.; KOBAYASHI, S.; TAKAHASHI, M. Effects of purple sweet potato anthocyanins on development and intracellular redox status of bovine preimplantation embryos exposed to heat shock. Journal of Reproduction and Development, Tokyo, v. 53, n. 3, p. 605-614, 2007.

SALZANO, A.; ALBERO, G.; ZULLO, G.; NEGLIA, G.; ABDEL-WAHAB, A.; BIFULCO, G.; ZICARELLI, L.; GASPARRINI, B. Effect of resveratrol supplementation during culture on the quality and cryotolerance of bovine in vitro produced embryos. Animal Reproduction Science, Amsterdam, v. 151, n. 3, p. 91-96, 2014.

SANTOS, M. V. O.; QUEIROZ NETA, L. B.; BORGES, A. A.; PEREIRA, A. F. Influence of commercially available follicle stimulating hormone on the in vitro maturation of bovine oocytes. Semina: Ciências Agrárias, Londrina, v. 38, n. 3, p. 1393-1402, 2017.

SAPANIDOU, V.; TAITZOGLOU, I.; TSAKMAKIDIS, I.; KOURTZELIS, I.; FLETOURIS, D.; THEODORIDIS, A.; TSANTARLIOTOU, M. Antioxidant effect of crocin on bovine sperm quality and in vitro fertilization. Theriogenology, New York, v. 84, n. 8, p. 1273-1282, 2015.

SASIDHARAN, S.; CHEN, Y.; SARAVANAN, D.; SUNDRAM, K. M.; LATHA, L. Y. Extraction, isolation and characterization of bioactive compounds from plants' extracts. African Journal of Traditional, Complementary and Alternative Medicines, Ile-Ife, v. 8, n. 1, p. 1-10, 2011.

SOLLECITO, N. V.; PEREIRA, E. C. M.; GRÁZIA, J. G. V. de; LEITE, A. C.; COUTO, B. V. R.; ANDRADE, V. B.; MAGALHÃES, E. B.; BORGES, Á. M. In vitro production of bovine embryos in culture medium containing different concentrations of antioxidant extracted from Lippia oil origanoides. Animal Reproduction, Belo Horizonte, v. 13, n. 3, p. 490-490, 2016.

SOUZA-FABJAN, J. M.; PEREIRA, A. F.; MELO, C. H.; SANCHEZ, D. J.; OBA, E.; MERMILLOD, P.; MELO, L. M.; TEIXEIRA, D. I. A.; FREITAS, V. J. Assessment of the reproductive parameters, laparoscopic oocyte recovery and the first embryos produced in vitro from endangered Canindé goats (Capra hircus). Reproductive Biology, Olsztyn, v. 13, n. 4, p. 325-332, 2013.

SOVERNIGO, T. C.; ADONA, P. R.; MONZANI, P. S.; GUEMRA, S.; BARROS, F. D. A.; LOPES, F. G.; LEAL, C. L. V. Effects of supplementation of medium with different antioxidants during in vitro maturation of bovine oocytes on subsequent embryo production. Reproduction in Domestic Animals, Linköping, v. 52, n. 4, p. 561-569, 2017. 
SUN, W. J.; PANG, Y. W.; LIU, Y.; HAO, H. S.; ZHAO, X. M.; QIN, T.; ZHU, H. B.; DU, W. H. Exogenous glutathione supplementation in culture medium improves the bovine embryo development after in vitro fertilization. Theriogenology, New York, v. 84, n. 5, p. 716-723, 2015.

SZMITKO, P. E.; VERMA, S. Red wine and your heart. Circulation, New York, v. 111, n. 2, p. 10-11, 2005.

TAKAHASHI, M. Oxidative stress and redox regulation on in vitro development of mammalian embryos. Journal of Reproduction and Development, Tokyo, v. 58, n. 1, p. 1-9, 2012.

TAKUMA, T.; SAKAI, S.; ICHIMARU, H.; JINNOUCHI, T.; KAEDEI, Y.; NAGAI, T.; TAKESHIGE, O. T. O. I. Effects of season and reproductive phase on the quality, quantity and developmental competence of oocytes aspirated from Japanese black cows. Journal of Reproduction and Development, Tokyo, v. 56, n. 1, p. 5559, 2010.

TAVANA, S.; EIMANI, H.; AZARNIA, M.; SHAHVERDI, A.; YAZDI, P. E. Effects of Saffron (Crocus sativus $\mathrm{L}$.) aqueous extract on in vitro maturation, fertilization and embryo development of mouse oocytes. Cell Journal (Yakhteh), Tehran, v. 13, n. 4, p. 259-264, 2012.

TOYODA, Y.; CHANG, M. C. Fertilization of rat eggs in vitro by epididymal spermatozoa and the development of eggs following transfer. Journal of Reproduction and Fertility, Cambridge, v. 36, n. 1, p. 9-22, 1974.

TVRDÁ, E.; LUKÁC, N.; LUKÁCOVÁ, J.; HASHIM, F.; MASSÁNYI, P. In vitro supplementation of resveratrol to bovine spermatozoa: effects on motility, viability and superoxide production. The Journal of Microbiology, Biotechnology and Food Sciences, Nitra, v. 4, n. 4, p. 336-341, 2015.
WANG, F.; TIAN, X.; ZHANG, L.; HE, C.; JI, P.; LI, Y.; TAN, D.; LIU, G. Beneficial effect of resveratrol on bovine oocyte maturation and subsequent embryonic development after in vitro fertilization. Fertility and Sterility, New York, v. 101, n. 2, p. 577-586, 2014.

WANG, Z.; FU, C.; YU, S. Green tea polyphenols added to IVM and IVC media affect transcript abundance, apoptosis, and pregnancy rates in bovine embryos. Theriogenology, New York, v. 79, n. 1, p. 186-192, 2013.

WANG, Z.; YU, S.; XU, Z. Improvement in bovine embryo production in vitro by treatment with green tea polyphenols during in vitro maturation of oocytes. Animal Reproduction Science, Amsterdam, v. 100, n. 1, p. 22-31, 2007.

WHITTINGHAM, D. G. Fertilization of mouse eggs in vitro. Nature, London, v. 220, n. 5167, p. 592-593, 1968.

YOU, J.; KIM, J.; LIM, J.; LEE, E. Anthocyanin stimulates in vitro development of cloned pig embryos by increasing the intracellular glutathione level and inhibiting reactive oxygen species. Theriogenology, New York, v. 74, n. 5, p. 777-785, 2010.

ZHONG, R.; ZHOU, D. Oxidative stress and role of natural plant derived antioxidants in animal reproduction. Journal of Integrative Agriculture, Beijing, v. 12, n. 10, p. 1826-1838, 2013.

ZULLO, G.; ALBERO, G.; NEGLIA, G.; CANDITIIS, C.; BIFULCO, G.; CAMPANILE, G.; GASPARRINI, B. L-ergothioneine supplementation during culture improves quality of bovine in vitro-produced embryos. Theriogenology, New York, v. 85, n. 4, p. 688-697, $2016 \mathrm{a}$.

ZULLO, G.; CANDITIIS, C.; PERO, M. E.; ALBERO, G.; SALZANO, A.; NEGLIA, G.; CAMPANILE, G.; GASPARRINI, B. Crocetin improves the quality of in vitro-produced bovine embryos: implications for blastocyst development, cryotolerance, and apoptosis. Theriogenology, New York, v. 86, n. 8, p. 1879-1885, $2016 b$. 
